\title{
Structure peculiarities and properties of magnesium oxide layers formed by a hybrid ion-plasma discharge system
}

\author{
Z.A.Duriagina, V.Ya.Pidkova, S.O.Olshevska \\ Lviv Polytechnical National University, 12 Bandera Str., \\ 79013 Lviv, Ukraine
}

Received 25 February, 2013

\begin{abstract}
The structure and properties of magnesium oxide layers formed by a hybrid ion-plasma discharge system were investigated. The layers consist of the MgO phase which possesses a high degree of polycrystallinity. Grains are formed by the island mechanism with their subsequent joining in clusters. The dielectric layers of magnesium oxide are uniformly distributed over the substrate surface. The average values of grains diameter and surface roughness that are 82.353 and $35.628 \mathrm{~nm}$, respectively, were found.
\end{abstract}

\begin{abstract}
Исследованы строение и свойства слоев оксида магния, сформированных гибридной ионно-плазменной разрядной системой. Слои состоят из фазы $\mathrm{MgO}$, которая обладает высокой степенью поликристалличности. Зерна формируются по островковому механизму с последующим объединением в кластеры. Диэлектрические слои оксида магния равномерно распределены по поверхности подложки. Установлены средние значения диаметра зерен и шероховатости поверхности, которые составляют 82,353 и 35,628 нм соответственно.
\end{abstract}

\section{Introduction}

Since the last century a constant tendency of changing the existing elementary base of tubular, spiral, rod electric heating devices by the surface-distributed resistive elements that can be made of metal, composite or semi-conductive materials has been observed. The main heating element requirements is providing the uniform distribution of temperature, constant heat flow of heat exchange and maximum heat removing on the contact surface.

Today this problem is solved by applying the intermediate heat carriers (water, air, oil), increasing hard massifs that transfer heat or using infrared irradiation. However these measures decrease the thermal coefficient of efficiency (TCE), increase the inertia, reduce the life time and increase the cost of the heat units [1].

In thermal devices with surface-distributed resistive elements, called the film heating elements (FHE), a resistive element in the form of a solid film or of a special pattern covers uniformly the substrate surface. Such design peculiarities of the resistive element provide a minimum difference between the heating element temperature and the environment, thus forming its main advantages. These include: universality, uniform distribution of the heat flow on the heat exchange surface, non-inertness, possibility of the heat power, increase of TCE, fire- and electric safety, no environment impact related with drying and ionization of air and so on.

A film heating element consists constructively of a substrate made of a thin-sheet dielectric material or a metallic sheet with electric insulation coating. A resistive electric heating functional element is prepared of a thin solid or a discontinuous film, a protective shell and contact electrodes. 
Table 1. Electrophysical properties of magnesium oxide

\begin{tabular}{|c|c|c|c|c|c|c||}
\hline$\lambda, \mathrm{V} /(\mathrm{m} \cdot \mathrm{K})$ & $T_{\text {exp }}, \mathrm{K}$ & $E, \mathrm{eV}$ & $\operatorname{tg} \delta$ & $\varepsilon, \mathrm{kV} / \mathrm{mm}$ & $\xi$ & $\alpha, 10^{-6}, \mathrm{~K}$ \\
\hline 28 & 2273 & 7.8 & $10^{-4}$ & $10-35$ & $8-10$ & $11.7-14.2$ \\
\hline
\end{tabular}

Table 2. Regimes of dielectric layers formation

\begin{tabular}{||c|c|c|c|c|c||}
\hline \hline Formation regime & Substrate & $\tau, \min$ & $P$, mm.mer.col & $E, \mathrm{~V}$ & $I, \mathrm{~A}$ \\
\hline Regime1 & $40 \mathrm{X} 13$ & 30 & $3 \cdot 10^{-2} \div 8 \cdot 10^{-3}$ & -14 & 40 \\
Regime2 & $40 \times 13$ & 20 & $(1.5 \div 2) \cdot 10^{-2}$ & -60 & 32 \\
\hline
\end{tabular}

The dielectric layer forms the insulation barrier between the substrate and the resistor. It must possess a corresponding dielectric strength and heat conductivity. To avoid cracking and breakage of the heating element the materials of the substrate, dielectric and resistant layers should have commensurable coefficients of linear expansion.

Magnesium oxide ( $\mathrm{MgO})$ is a prospective material to be used as a dielectric layer of the film heating elements. It is characterized by the high values of heat conductivity $(\lambda)$, exploitation temperature $\left(T_{\text {exp }}\right)$ and width of the exclusion zone $(E)$ with the optimal dielectric constant $(\xi)$ and disruption voltage $(\alpha)$ (Table 1). Magnesium oxide possesses a high chemical and thermal resistance and keeps high electrical resistance to temperatures up to about $1000^{\circ} \mathrm{C}$ [2].

Literature sources present several methods of preparation of MgO layers. These are: ion-beam precipitation, organometallic chemical precipitation from a steam phase, electron-beam evaporation, pulse-laser precipitation and spraying [3-5]. These methods are unsuitable for the electric layers formation in the film heating elements because of low efficiency [6].

The aim of this paper is to analyze a possibility of the ion-beam discharge system use for the formation of magnesium oxide as the dielectric layer for FHE.

\section{Experimental procedure}

The layers of $\mathrm{MgO}$ were formed applying the ion-plasma discharge system [7]. It is a multi-functional device that comprises a high-frequency source of helicon-discharge plasma and plasma-arc accelerators for CVD process realization. The use of the helicon source enables the constant action of argon ions on the substrate during technological process. In this way the adsorbed components of the residual medium are effectively extracted from the substrate surface. As a result the adhesion of the applied layers increases. A high degree of plasma flow ionization ( $>80 \%$ ) allows us to control the layers thickness during their application by the value of a charge which is integrally transferred on the substrate.

The process of ion-plasma spraying was carried out by two regimes (Table 2), that differ by the process duration $(\tau)$, potential shift on the substrate $(E)$, pressure $(P)$ and the plasma arc current $(I)$. Spraying was carried out in the oxygen atmosphere. The substrate was heated in the furnace installed immediately in the reaction chamber of the ion-plasma system. As a result the adhesion of the coating to the substrate became better. The finish cleaning of the substrate for $30 \mathrm{~min}$ was performed in a helicon plasma flow in the "column" regime. The reaction of magnesium oxidation was accompanied by coloring the plasma arc in a dark-green color.

Phase composition was investigated by the X-ray structure analysis. Arrays of the experimental XRD spectra were obtained on the automatic diffractometer STOE STADI P (manufactured by "STOE \& Cie GmbH" company, Germany) with a linear positionprecision detector PSD by the chart of Bragg-Brentano-geometry.

Filming was done in $\mathrm{Cu}_{\mathrm{K} \alpha 1}$ irradiation for reflection with a concave Johann type Ge-monochromator (111). Scanning angle was $2 \theta / \omega$, interval of angles $20.000 \leq 2 \theta^{\circ} \leq 117.905$ with a step of $0.015^{\circ}$ $2 \theta$, while a detector step was $0.480^{\circ} 2 \theta$ for the scanning time in a step $250-275$ sec. In this case the filming temperature was $T=$ $24.5 \pm 0.5^{\circ} \mathrm{C}, U=40 \mathrm{kV}, J=37 \mathrm{~mA}$. XRD spectra were decoded using the software STOE WinXPOW [8] and PowderCell [9] by comparing experimental and standard X-ray profiles. The crystal structure of the phases in the chosen specimens was specified by Rietveld method [10] applying software FullProf. 2k (version 5.20) [11]. 


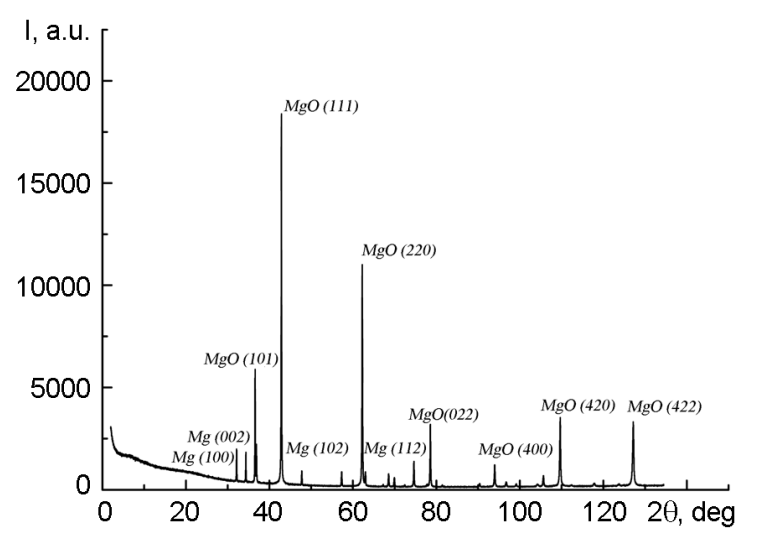

Fig. 1. XRD spectra of the layer after ionplasma spraying with MgO.

The structure of the created layer surface was investigated by an electron microscope JSM-6490LV (JEOL, Japan), equipped with an analytic device for elementary analysis (energy-dispersion spectrometer INCA Energy+Oxford). The thickness, structure and elementary composition were determined on the scanning electron microscope with an analyzer PEMMA-102-02. Surface topography was investigated by an atomic-force microscope Solver. The analysis of the obtained images was identified by Image Analysis 2 software.

\section{Results and discussion}

In the dielectric $\mathrm{MgO}$ surface layers the phase of $\mathrm{MgO}$ of structural type $\mathrm{NaCl}$, space group $F m-3 m$, was identified by diffraction $\mathrm{X}$-ray structural analysis (Fig. 1). An elementary cell parameter of this phase is $a$ $=4.215 \AA$. Diffraction peaks of the phase $\mathrm{MgO}$ - (101), (111), (220), (022), (400), (420), (422) testify to its polycrystallinity. Diffraction peaks (100), (002), (102), (112), that correspond to pure magnesium are also found. The presence of this phase shows that in the process of ion-plasma spraying not all magnesium ions which have been re- leazed from the cathode are fast enough to enter into an oxidation reaction. As a result, on the target (substrate) surface, except magnesium oxide of stoichiometric composition, a small amount of pure magnesium is transferred. The presence of pure magnesium has a negative influence on the electrophysical properties of the dielectric layer.

Morphological structure of the $\mathrm{MgO}$ dielectric layer surface, formed by the parameters of the first regime, is presented in Fig. 2. The layer structure consists of round shape grains with different dispersion. The grain sizes ranges from $70 \mathrm{~nm}$ to $20 \mu \mathrm{m}$. Grains grow by the island mechanism where the formed grain is the basis for creation of new centers of crystallization and their subsequent growth (Fig. 2b). Thus, the new-formed grains are grouped in clusters of different size. Owing to their specific construction the grains have great specific interfacial area. It is characterized by the presence of leafs, formed in the perpendicular direction (Fig. 2a). The thickness of the identified leafs is 10-20 nm. Such a mechanism of the layer structure formation and the difference in the formed grain clusters size causes significant porosity of the dielectric layer thus increasing greatly its absorbability.

To analyze in more detail the composition and structure of magnesium oxide layers they were photographed in elastic reflected electrons in COMPO regime and then the local micro X-ray spectral analysis of the surface was also performed. As seen from Fig. 3 the layer is uniform by composition what is proved by the presence of oxygen and magnesium peaks typical of $\mathrm{MgO}$ compounds of stoichiometric composition. Interstitial inclusions of a light color, located in some places outside the layer surface, correspond to pure iron, which presence is caused by peculiarities of technological process of ion-plasma spraying [6].
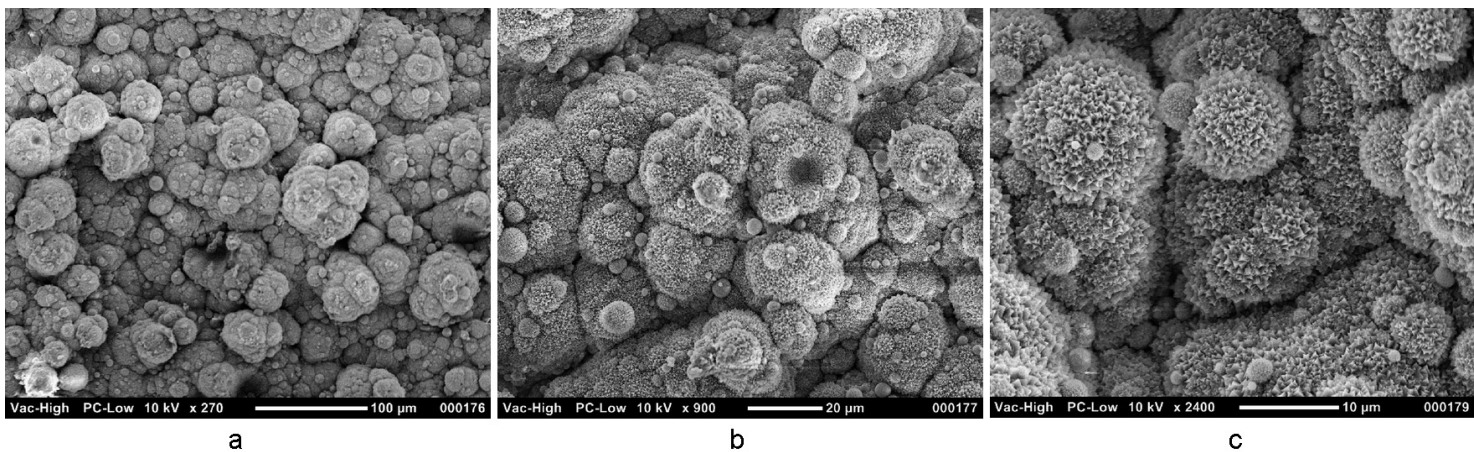

Fig. 2. Morphology of MgO surface structure. 


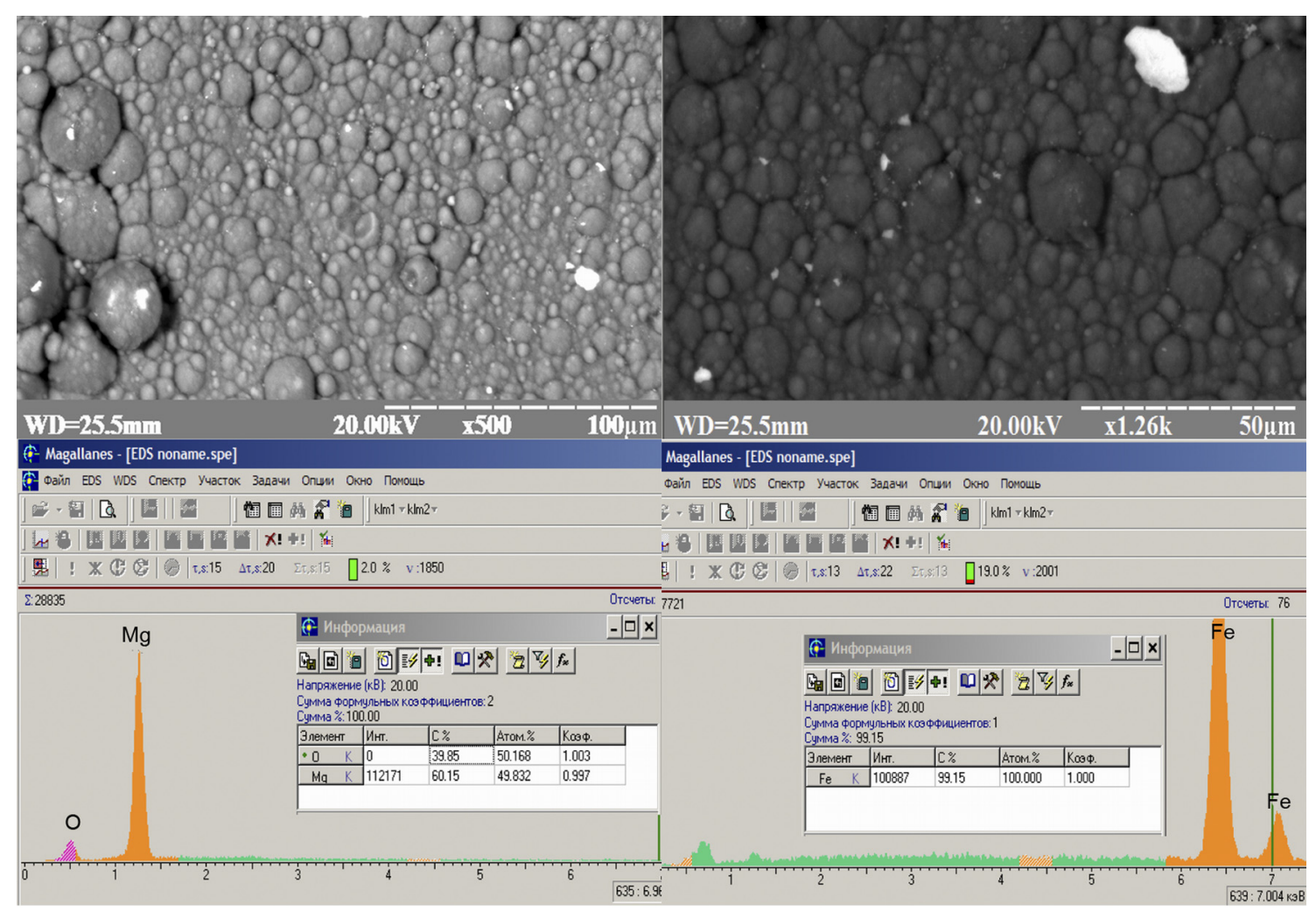

Fig. 3. Local micro X-ray spectral analysis of the layer surface in the COMBO regime.

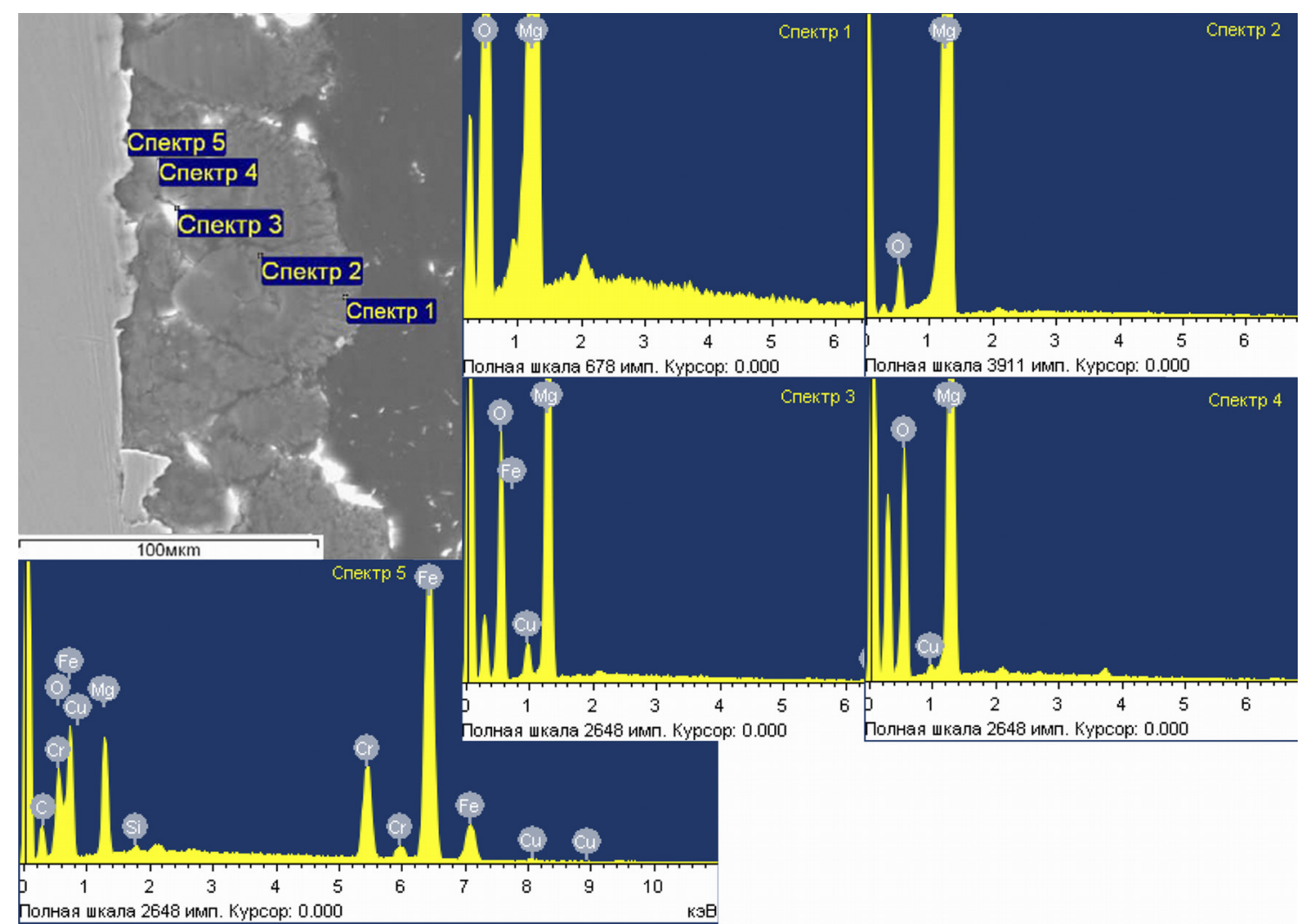

Fig. 4. Local micro X-ray spectral analysis of the depth of MgO layer. 


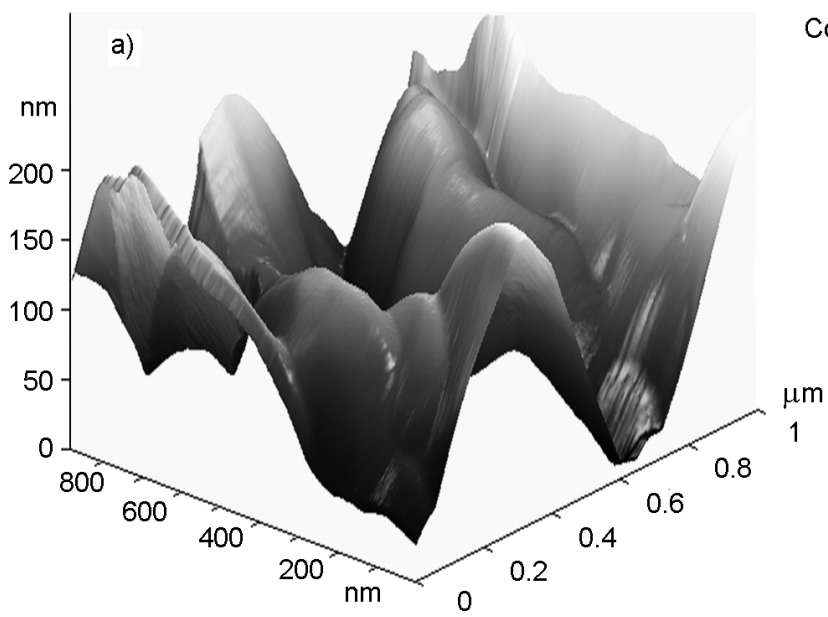

Grain analysis report threshold: $145 \mathrm{~nm}$

\begin{tabular}{|c|c|c|c|c|c|c|c|c|}
\hline & SD & 1 & 2 & 3 & 4 & 5 & 6 & 7 \\
\hline $\mathrm{D}, \mathrm{nm}$ & 82,353 & 258,824 & 247,059 & 105,883 & 231,373 & 3,922 & 180,392 & 117,647 \\
\hline
\end{tabular}

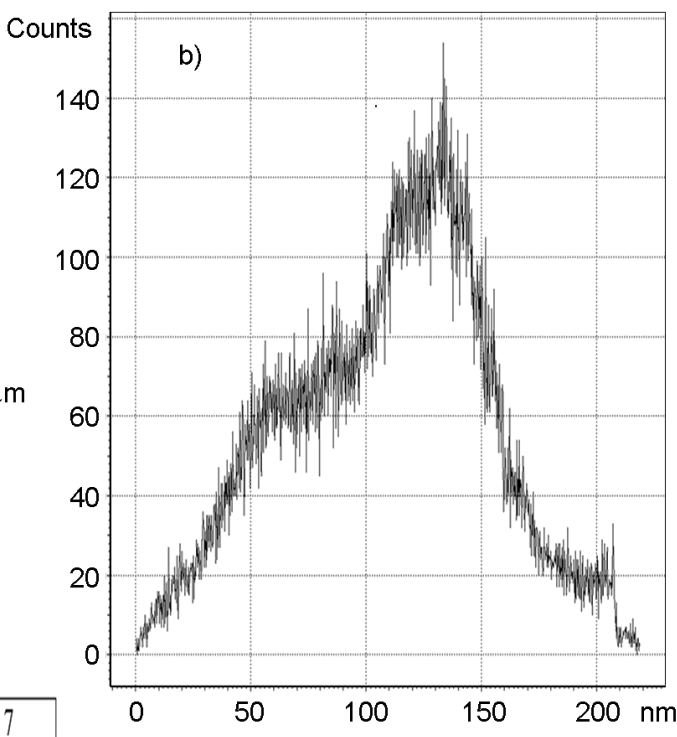

Max: 218,628 nm; Average roughness, Sa: 35,628 nm

Fig. 5. Three-dimensional ACM-image of surface topology (a) and profile diagram (b) of MgO.

Investigations by the electron microscope of the edge section microstructure of the dielectric layer demonstrated that the layer thickness is $60-65 \mu \mathrm{m}$. The breakage of the layer continuity is observed at the interfaces of large clusters. In the case of large magnifications the large-axial crystallites oriented perpendicularly to the substrate are identified (Fig. 4b).

Local micro X-ray structural analysis of depth of the dielectric MgO layer showed that the main phase in the layer volume was MgO (Fig. 5 spectrum 1, 2). In adiition atoms of the interstitial elements of iron and copper which we concentrated in pores and at the interface of large cluster fragments (spectrum 3,4) were detected. Spectrum 5 (Fig. 5) corresponded to the elementary composition of 40X13 steel substrate.

Quantitative analysis of the surface topology of the dielectric MgO layer carried out by the method of atom-force microscopy enabled the detection the nano-sized fragments in its structure. Particularly the analysis of the surface microrelief at a height of $145 \mathrm{~nm}$ showed that the grain diameter (D) varied from 3.921 to $258.824 \mathrm{~nm}\left(D_{c e p}=82.353 \mathrm{~nm}\right)$. In this case the average surface roughness was $35.628 \mathrm{~nm}$ with a maximum height of protrusions $-218.628 \mathrm{~nm}$. As seen from the profile diagram (Fig. 5 , b), the protrusions of the height from 50 to $150 \mathrm{~nm}$ occupy the major part of the surface.

When analyzing the specific features of the $\mathrm{MgO}$ dielectric layers structure it was established that by using the hybrid ionplasma system it is possible to form the dielectric layers of uniform phase composition with nano-size fragments of structure. Grains of different size which are characterized by the island mechanism of growth are joined in clusters. It should be mentioned that the major specific portion of the dielectric layer volume occupy grains with commensurable size. This decreases the length of interfaces, thus causing the reduction of porosity. At the clusters interfaces the atoms of iron and copper are accumulated, giving the less dielectric strength of the layers. Thus, the further splitting of fragments of the dielectric layer structure and decrease of the negative influence of admixtures will lead to the increase of its insulation characteristics.

\section{Conclusions}

It was established that the hybrid ionplasma discharge system can form the dielectric layers of uniform phase composition with nano-size fragments of structure.

The main phase of the layer is $\mathrm{MgO}$ of $\mathrm{NaCl}$ structural type, space group $\mathrm{Fm}-3 \mathrm{~m}$ with a high degree of polycrytallinity.

Layer surface contains the high-dispersive nano-sized fragments. In particular the average values of the grain diameter and the surface roughness are $82.353 \mathrm{~nm}$ and $35.628 \mathrm{~nm}$, respectively. In this case magnesium oxide layer is uniform by thickness and is characterized by the insignificant porosity. 


\section{References}

1. D.A.Geodakian, Film Electric Heaters. I. Functional and Structural Peculiarities (a Review), Vol.61, Issue 2 (2008), p.228 [in Russian].

2. Tie-Jun Zhu, Li Lu, AMMNS, 1 (2003).

3. M.V.Cole, E.Ngo, S.J. Appl.Phys.Lett., 92, 072906 (2008).

4. C.Bondouxa, P.Pren'e a, P.Belleville, J.Eur. Cer. Society, 25, 2795 (2005).

5. T.W.Kim, Y.S.You, J.Appl.Surf.Sci., 180, 162 (2001).

6. Z.A.Duriagina, V.Ya.Pidkova, S.A.Bespalov, in: Probl. Corrosion and Corrosion Protect.
Mater.: in 2 Vol./Special Issue of PhChMM, Vol.2 (2012), p.506 [in Ukrainian].

7. Z.A.Duriagina, S.A.Bespalov, V.Ya Pidkova, D.P.Polotskyi, Metallophys. New Technol., 33, 393 (2011).

8. Store Win XP OW, version 3.03 , Stoe \& Cie $\mathrm{GmbH}$, Darmstadt (2010).

9. W.Kraus, G.Nolze, Powder Cell for Windows (version 2.4), Berlin: Federal Institute for Materials Research and Testing, March 2000.

10. R.A.Young (Ed.), The Rietveld Method, IUCr Monographs of Crystallography, Vol.5, Oxford University Press, New York (1993).

11. J.Rodriguez-Carvajal, Commission on Powder Diffraction (IUCr), Newsletter, 26, 12 (2001).

\section{Особливості будови та властивостей шарів оксиду магнію, сформованих гібридною іонно-плазмовою розрядною системою}

\section{З.А.Дурягіна, В.Я.Підкова, С.О.Ольшевска}

\footnotetext{
Досліджено будову та властивості шарів оксиду магнію, сформованих гібридною іонно-плазмовою розрядною системою. Шари складаються з фази $\mathrm{MgO}$, яка має високий ступшнь полікристалічності. Зерна формуються за острівковим механізмом 3 наступним об’єднанням у кластери. Діелектричні шари оксиду магнію рівномірно розподілені за поверхнею підкладки. Встановлено середні значення діаметру зерен та шорсткості поверхні, які становлять 82,353 і 35,628 нм відповідно.
} 